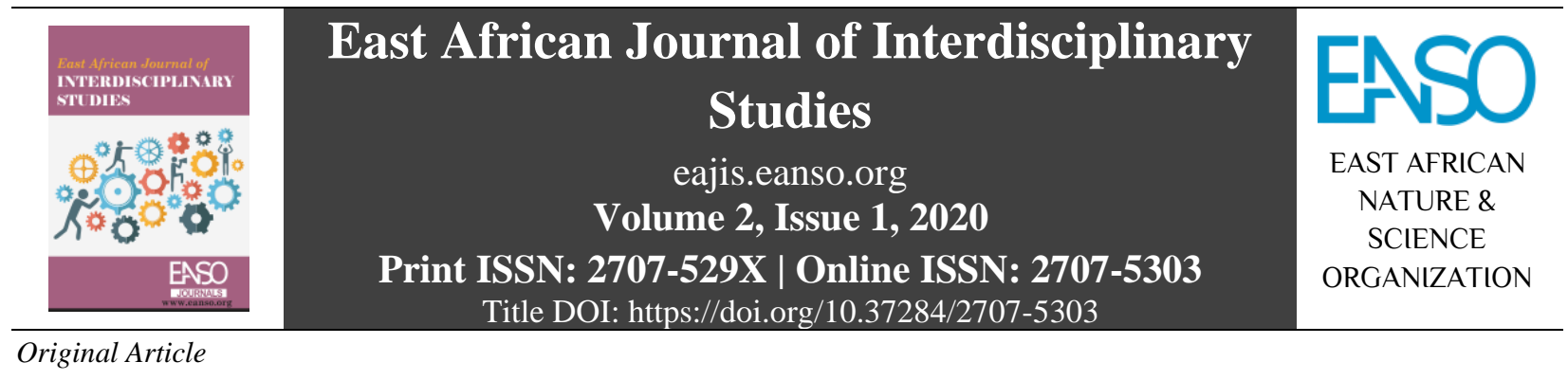

\title{
Role of Financial Rewards in Enhancing Academic Staff Performance in Public Universities in Uganda
}

Joseph Rwothumio ${ }^{1,2, *}$, Daniel Mange Mbirithi, $P h D^{2} \&$ Wilfrida Itolondo, $P h D^{2}$

${ }^{1}$ Kyambogo University, P. O. Box 1, Kyambogo, Kampala, Uganda.

${ }^{2}$ Kenyatta University P. O. Box 43844-00100, Nairobi, Kenya.

*Author for Correspondence Email: rwothumiojoseph@yahoo.com.

Article DOI: https://doi.org/10.37284/eajis.2.1.256

\section{Date Published: ABSTRACT}

16 December 2020 This article examined the financial reward practice implemented by universities to improve on the performance of lecturers in Uganda's

Keywords: public universities. The main objectives of the research were to investigate the relationship between financial reward and teaching and

Financial Rewards,

Academic Staff,

Performance,

Public Universities. research outputs of academic staff in selected public universities. A mixed method design using convergent parallel approach was employed to collect and analyse data obtained from the study. A sample of 299 participants was drawn from academic staff, directors of human resources, and Vice chancellors. Results indicated a weak positive relationship between financial reward and academic staff teaching output in public universities $(\mathrm{r}=0.282, \mathrm{p}<0.01)$. There existed further a weak positive relationship between financial reward and academic staff research output $(\mathrm{r}=0.211, \mathrm{p}<0.01)$. It would suffice to effect appropriate financial rewards to academic staff based on a living wage.

\section{APA CITATION}

Rwothumio, J., Mbirithi, D. M., \& Itolondo, W. (2020). Role of Financial Rewards in Enhancing Academic Staff Performance in Public Universities in Uganda. East African Journal of Interdisciplinary Studies, 2(1), $207-223$. https://doi.org/10.37284/eajis.2.1.256

\section{CHICAGO CITATION}

Rwothumio, Joseph, Daniel Mange Mbirithi, and Wilfrida Itolondo. 2020. "Role of Financial Rewards in Enhancing Academic Staff Performance in Public Universities in Uganda”. East African Journal of Interdisciplinary Studies 2 (1), $207-223$. https://doi.org/10.37284/eajis.2.1.256.

\section{HARVARD CITATION}

Rwothumio, J., Mbirithi, D. M. and Itolondo, W. (2020) "Role of Financial Rewards in Enhancing Academic Staff Performance in Public Universities in Uganda", East African Journal of Interdisciplinary Studies, 2(1), pp. 207-223. doi: 10.37284/eajis.2.1.256. 


\section{IEEE CITATION}

J. Rwothumio, D. M. Onyango, and W. Itolondo, "Role of Financial Rewards in Enhancing Academic Staff Performance in Public Universities in Uganda”, EAJIS, vol. 2, no. 1, pp. 207-223, Dec. 2020.

\section{MLA CITATION}

Rwothumio, Joseph, Daniel Mange Mbirithi, and Wilfrida Itolondo. "Role of Financial Rewards in Enhancing Academic Staff Performance in Public Universities in Uganda". East African Journal of Interdisciplinary Studies, Vol. 2, no. 1, Dec. 2020, pp. 207-223, doi:10.37284/eajis.2.1.256.

\section{INTRODUCTION}

Most public universities offer a wide range of financial rewards and benefits in order to enhance academic staff performance in public universities. Rasheed, Aslam and Sarwar (2010) argue that increased salary packages and revised teaching compensation packages have been used to enhance the performance of teaching staff in academic institutions. In Uganda, Barifaijo and Nkata (2009) report that failure by universities to ensure equitable rewards has negatively affected the performance of academic staff. Reports of poor lecturer performance in universities in Uganda continue to prevail (McGregor, 2007; NCHE, 2016). The concern has been on public universities not fully implementing financial reward practices in their human resource manuals.

So far, a considerable effort has been made to increase the financial rewards of teaching staff in Ugandan public universities. Financial rewards involve remuneration of staff as provided for in their employment contracts. Aquinis (2013) affirms that financial rewards may include basic pay, cost-of-living adjustments, short term and long-term incentives. Financial reward is critical in rewarding staff for their effort and innovation, and has a determining effect on the level of performance of employees. Qureshi and Sajjad (2015) argue that it is the primary focus of many staff in organisations. Employees focus on financial reward because they use the package to solve their daily survival demands.

Public universities in Uganda have clearly spelt out terms and conditions for rewarding staff in their respective human resource manuals. The financial rewards which are evident in most of the public university human resource manuals are salaries, allowances, honorarium, gratuity and extra load payments (Mbarara University, 2009; Makerere University, 2010; Kyambogo University, 2015 \& Gulu University, 2016). The ministry of finance, planning and economic development financial reports 2014/15, 2015/16 and 2016/17 show that the funds that were spent on salaries and allowances in public universities increased from 99.316 billion in 2015 to 201.979 billion in 2017 and allowances increased from 13.04 billion in 2015 to 47.76 billion in 2017(Table 1).

Table 1: Public Universities Expenditure on Salaries and Allowances

\begin{tabular}{|c|c|c|c|c|c|c|}
\hline \multirow[t]{2}{*}{ UNIVERSITY } & \multicolumn{2}{|c|}{ Billion shillings } & \multicolumn{2}{|c|}{ Billion shillings } & \multicolumn{2}{|c|}{ Billion shillings } \\
\hline & Salaries & Allowances & Salaries & Allowances & Salaries & Allowances \\
\hline Busit & 8.842 & - & 11.167 & 2.466 & 15.842 & 1.97 \\
\hline Kyambogo & 16.540 & 10.6 & 23.234 & 0.28 & 39.974 & 19.94 \\
\hline
\end{tabular}


East African Journal of Interdisciplinary Studies, Volume 2, Issue 1, 2020

Article DOI: https://doi.org/10.37284/eajis.2.1.256

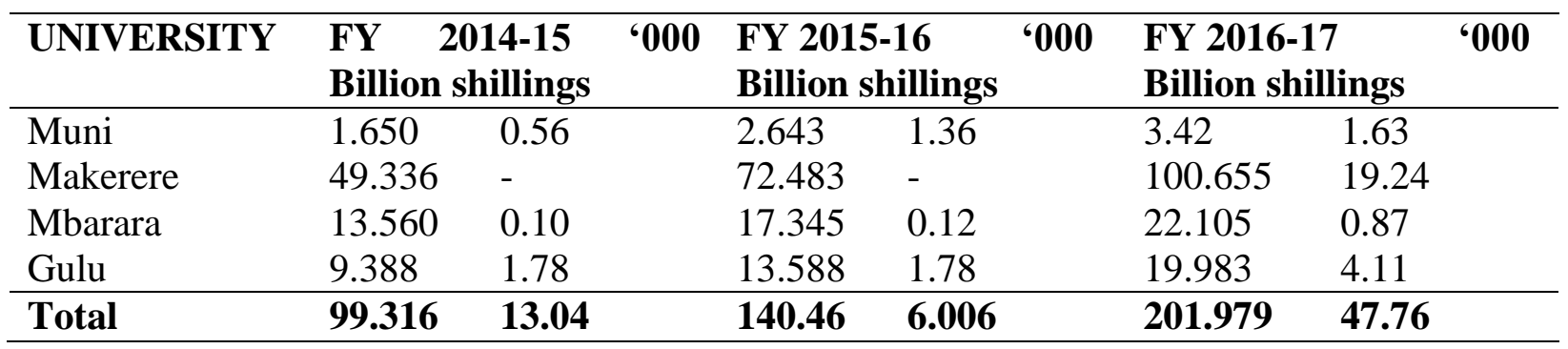

Source: Ministry of Finance, Planning and Economic Development reports (2014-2017)

Despite the above increase in funds received by public universities for salaries and allowances, dissatisfaction with and irregularities in payments of salaries, allowances and benefits have been a cause of strikes. The level of job performance by academic staff tends to be low in public universities in Uganda (NCHE, 2015). Harmonization of academic staff salaries in public universities has been undertaken by government with great effort (Basheka, 2014). This, however, is yet to bear positive results due to the fact that each university has its own way of catering for the financial demands of its staff. For instance, Inspector General of Government (2015) noted that Kyambogo University pays twenty-nine (29) different types of allowances to staff which is far higher than those outlined in terms of service of other public universities.

Table 2: Public Universities Expenditure on Research Consultancy and Publications

\begin{tabular}{|c|c|c|c|}
\hline \multirow[t]{2}{*}{ University } & $\begin{array}{l}\text { FY 2014-15 '000 Billion } \\
\text { Shillings }\end{array}$ & $\begin{array}{l}\text { FY 2015-16 '000 } \\
\text { Billion Shillings }\end{array}$ & $\begin{array}{l}\text { FY 2016-17'000 Billion } \\
\text { Shillings }\end{array}$ \\
\hline & $\begin{array}{l}\text { Consultancy and } \\
\text { Publications }\end{array}$ & $\begin{array}{l}\text { Consultancy and } \\
\text { Publications }\end{array}$ & $\begin{array}{l}\text { Consultancy and } \\
\text { Publications }\end{array}$ \\
\hline Busitema & 0.22 & 0.23 & 0.22 \\
\hline Kyambogo & 0.05 & 0.07 & 1.41 \\
\hline Muni & 0.06 & 0.11 & 0.36 \\
\hline Makerere & 14.25 & 19.84 & 35.66 \\
\hline Mbarara & 0.08 & 0.07 & 0.23 \\
\hline Gulu & 0.48 & 0.72 & 0.52 \\
\hline Total & 15.14 & 21.04 & 38.4 \\
\hline
\end{tabular}

Source: Ministry of Finance, Planning and Economic Development reports (2014-2017)

Report (HESA, 2014) on the compensation of academic staff in South African universities had also indicated that staff remuneration had a positive influence on the level of output. In another instance, Mutahi and Busienei (2015) carried out a study on human resource management practices and performance of
Kenyan public universities. According to the findings, public universities need to place more emphasis on management of compensation than in practices of recruitment and training. Though Mugizi, Bakkabulindi and Bisaso (2015) notwithstanding looked at antecedents of commitment in universities in Uganda 
among the teaching staff, the focus of the study was on commitment and not the performance of teaching staff in public universities. This study focused on the correlation between financial practice and academic staff performance in selected public universities in Uganda.

\section{Statement of the Problem}

Public universities in Uganda are implementing financial rewards to enhance academic staff performance as provided for in their human resource manuals. Public universities are also implementing the recommendations by the NCHE (2016) on staff financial reward as key human resource management practices among others to improve academic staff performance in universities. Budget performance frameworks for financial years 2014/15, 2015/16 and 2016/17 for public universities in Uganda, reveal an increase in allocation of funds to staff salary, increments and research activities. Despite these moves, the performance of academic staff in these institutions has not improved to the expected standards. Reports of poor lecturer performance in terms of ineffective teaching, low records of publications and inability to attract and win projects continue to prevail in most public universities in Uganda (McGregor, 2007; NCHE, 2016). This scenario has created the need for a study to be conducted to establish whether there is any relationship between financial rewards and academic staff performance in Ugandan public universities.

The objectives of the paper were to examine the relationship between financial reward and academic staff teaching output in selected public universities in Uganda and explain the relationship between financial reward and academic staff research output in selected public universities in Uganda. The formulated Null hypotheses included:

$H_{O 1}$ : Financial reward has no statistically significant relationship with academic staff teaching output.

$H_{O 2}$ : Financial reward has no statistically significant relationship with academic staff research output.

\section{THEORETICAL FRAMEWORK}

The paper used the social exchange theory espoused by Homans (1958) and reviewed by Blau (1964) to explain what influences social behaviour in terms of interchange between material goods and non-material ones. According to Blau (1964), social exchange theory is a fundamental unit of social life, in which social structures are entrenched. He examined the process of exchange as the microfoundation of macro-sociological occurrences. Organisations that give much financial rewards get much from them, in form of high levels of job performance. It also added that employees would be under pressure to give back to their employers in terms of superior performance as per the target set. In effect, the propositions of social exchange theory indicated financial exchanges that employees were exposed to in organisations might lead to better job performance.

\section{LITERATURE REVIEW}

Financial reward is still a critical factor in stimulating staff performance in organisations. Agwu (2013) describes reward as pay arising from the satisfactory performance of duty. Pratheepkanth' conducted a study (2011) in Sri 
Lankan commercial bank on the influence of compensation system on the motivation of employees. The study revealed that higher rewards led to higher employee motivation. It was recommended among others that management must create supportive work environments and intensify salary schemes to cater for holidays, bonuses, pensions and overtime workloads.

Tufail and Sajid (2015) conducted a related study to establish the relationships between reward, work setting and employee motivation in Pakistan banking industry. The researchers used a correlational research design. The results showed a relationship between reward practice and motivation of employees. They suggested that banks should design and provide work environments that could enhance the motivation of employees. The study investigated the relationships between financial reward and academic staff teaching output. Another study was done by Aslam et al., (2015) on the impact of reward practice on the performance of organisations in Pakistan. Analysis of data was completed using analysis of variance (ANOVA). The research concluded that effective implementation of rewards greatly affected the performance of employees and boosted their efficiency.

Al-Nsour (2012) examined the influence of monetary and moral inducements on employee output in universities in Jordan. The research aimed at identifying the reality and importance of universities in Jordan in satisfying the needs of society, understanding the approaches in implementing incentives, identifying financial as well as moral incentives adopted and understanding the performance of organizations in universities in Jordan.
McClelland's theory of motivation guided the study. Analysis of data employed multiple regressions to verify the study assumptions. Results revealed a substantial positive linkage between financial and moral incentives with learning and growth in universities in Jordan. The second hypothesis was restated as there is a substantial association between monetary and moral inducement in universities in Jordan. Thirdly, the hypothesis was restated as, statistically, there exists a significant correlation between monetary and moral inducements as well as the satisfaction of customers in universities in Jordan.

Akter and Husain's study (2016) focused on the effect of reward on job performance among employees of public companies in Bangladesh. In their study, they examined the linkage between reward and performance of jobs. Data was analysed using Pearson correlation. The findings revealed a high and substantial association between reward and performance of the job. The research recommended that the findings have to be disseminated to help researchers and business leaders to help identify ways of improving the policy and strategy of reward for addressing effective performing employees.

In Uganda, Musenze et al. (2013) conducted research about the effects of reward systems on performance in organizations in private universities in Uganda. They reported that financial compensation had a positive correlation with performance $(\mathrm{r}=0.655, \mathrm{p}<$ $0.05)$, non-monetary rewards had positively influenced performance $(\mathrm{r}=0.551, \mathrm{p}<0.05)$ and a further positive and substantial linkage existed between the management of reward and 
performance in organizations $(\mathrm{r}=0.641, \mathrm{p}<$ $0.01)$.

The study by Kathombe, Kipchumba and Kirui (2018) examined how strategies of motivation affected the performance of staff in universities in Kenyan. The research purposed to: establish the linkage between motivational strategies and staff output, the influence of non-monetary compensation on staff output and to determine the pooled influence of monetary and nonmonetary compensation on staff output. The research design was descriptive in nature. A sample of 242 academic staff participated in the research. The collection of primary data was by use of a questionnaire. Purposive sampling was used to select two universities. Analysis of collected data used correlational analysis; Pearson correlation and multiple regressions were deployed to ascertain the effect of the predictor variable on the outcome variable. The finding confirmed a correlation between monetary rewards and staff performance. Findings confirmed that monetary compensation had an influence on staff output. Money plays an important role in staff motivation and enhances their level of output. Conclusively, more use of monetary compensation has the potential to drive staff output to a greater level. The study finally found that the linkage between monetary and non-monetary compensation has a positive association with performance. However, Sahoo and Mishra (2012) observed that monetary compensation package contain salary, pay based on promotion and incentives. Incentives could be a source of competitive advantage. Non-monetary compensation entails training, enrichment of jobs, progress in career and work setting.
In a study by Hashim et al. (2017) on the impact of three human resources management elements; reward, advancement and evaluation of performance on outputs of teachers in private universities in Peshawar, KPK, Pakistan. Three hypotheses guided the study. Compensation practice has a positive correlation with the performance of employee and promotion practice has a positive correlation with employee performance. Data was collected from 136 respondents using a Questionnaire. The researchers analysed data using Pearson correlation coefficient. Results found that human resource management practices had a substantial positive influence on staff output. Compensation practice with 0.47 is strongly and positively correlated with teacher performance in private universities. Performance evaluation with 0.38 showed a positive and significant relationship with teacher performance. Promotion practice with 0.44 indicated a strong positive correlation with teacher performance in Peshawar private universities. The study concluded that if human resource practices were adopted in organisations with better incentives and attractive packages then the performance of teachers can be enhanced. A proper paycheck and balance on a teacher could improve the performance of teachers.

Horodnic and Zait (2015) studied the association between motivation and research productivity in a system of a university under transition. The study aimed at correlating productivity of research with motivation. Data collection employed a questionnaire survey. Analysis of data was by use of the Tobit regression model. The results revealed that internal motivation is positively associated with productivity of research, whereas external 
motivation is negatively related. The findings implied researchers who valued their work took a strong interest in it and were very effective. Researchers who were motivated externally transfer their energy towards undertakings which had better monetary benefits in a sector experiencing evolution.

Chen et al. (2010) undertook an analysis on the productivity of research in the faculty of accounting through an exploratory study. The study aimed at examining productivity in research, the internal and external motivators of conducting research. This study found that there was a difference in research productivity among holders of doctorate degrees versus non-doctoral granting programmes. The most interesting extrinsic rewards included promotions, pay rises and reduction in teaching allocation which tend to be preferred.

Frolich and Klitkou (2014) presented a paper investigating the patterns of research publications in the Norwegian research funding model. The overall question was how does performance funding impact the production of research publications? Data was collected by the use of document analysis, exhaustive interviews and survey data. Results demonstrated that from the interviews and interactions research funding based on publication is perceived to be contributing to a shift in the pattern of publishing to a more quality and internationally oriented track. However, an increment in publication volume is not a total guarantee for academic quality. Members interviewed seem to support performance funding to enhance more publications. This study used both interview guide and questionnaires. The quantitative data generated were analysed by the use of the Pearson correlation approach in data analysis.

Quan, Chen and Shu (2016) published a paper on either publish or impoverish, an inquiry of the system of financial compensation of science in China (1996-2016). The research purposed to present the policy in China on compensation based on the cash-perpublication. The research approach involved document analysis concerning the compensation policy on cash-per-publication in one hundred Chinese universities. The study revealed that universities in China provide money ranging from thirty to one hundred sixty-five thousand Dollars (USD) for articles published in recognized journals and indexed by the science-based web. The study concluded that most Chinese universities often apply awards to academicians for their performance in research hence, advancing the productivity of publication in national research.

Omuya (2018) examined the compensation of staff performance in Kenyan public universities. It employed a survey method. The respondents included all human resource workers in selected public universities with a sample of 125 respondents. The main primary data collection instrument was a questionnaire and secondary data were obtained from literature developed by scholars. The study used regression analysis model. Results revealed that compensation and rewards also contributed to employee performance. The research conclusively recommended that higher education institutions especially public oriented should adhere to the guidelines of human resource as stipulated in the practice of human resource management to enhance output and productivity. 
Furthermore, Balakrishnan (2013) conducted a study to explore the methods that can be applied to raise the level of performance in research in the region of MENA. The research employed exploratory design. Interview was conducted for academicians, people responsible for funds for research, publications and industry-based seasoned administrators. Data were collected from available scholarly, industrial and non-governmental organizations' archives, workshops and presentations. The results revealed obstacles and schemes to propel research forward in three folds: the government which is in charge of policymaking, the industrial conditions prevailing in the market and the higher education institutions. The study noted that worldwide $77 \%$ of researchers concentrated in five countries namely United States of America (20\%), Europe (20\%), China (20\%), Japan $(10 \%)$ and Russia (7\%). Market factors focus on data access, data quality and collaboration. Collaboration with industry narrows the gap between academic research and practice. Institutional factors considered faculty publications and grants.

The study by Akinfolarian and Ehinola (2014) focused on motivation and effective academic staff performance in higher education institutions. Research questions on which the study was grounded included: what are the strategies of motivation leaders of higher education institutions use? What are the commonly used strategies by leaders of higher education institutions? What indices aid performance of academic staff? The design used in the research was descriptive survey. Data were collected from teaching staff and departmental heads. Data were collected using a Likert scale questionnaire on 4 points. Data were analysed using frequencies and percentages. The findings showed that stimulus for ingenuity and invention, recognition for sincere exertion, honour and appreciation on attainment facilitates lecturer output in any university. The study made recommendations among others was swift handling of remuneration as a measure to promote targeted outputs.

In a paper published by Ubogu (2019) in Nigerian Delta state concerning the hindrances influencing research in education. The hypotheses for the study were: academic integrity issues do not significantly constitute a major challenge to the uptake of educational research findings in Nigeria. The second hypothesis was scientific methods employed do not significantly constitute a major challenge to educational research findings in Nigeria. The study showed that the absence of a clear-cut philosophy of research in education at the national level, inadequate budgetary allocation, lack of appropriate policy-making bodies and inadequate special funds for research activities in Nigeria.

\section{METHODOLOGY}

The study employed mixed method research design. This study adopted a quantitative dominant mixed methodology. The research approach chosen was quantitative with a positivist orientation. To enrich the study findings the researchers recognised the addition of qualitative data approaches. Data were collected on financial rewards to establish its relationship with academic staff teaching and research outputs. Financial rewards, academic staff teaching and research outputs are real occurrences that can be measured and analysed using Pearson correlation. 
The independent variable was financial reward while the dependent variable was academic staff performance. The academic staff performance focused on teaching output as measured by teaching ten hours weekly; preparing course outlines; timely assessment of students; timely marking and return of scripts; timely submission of marks to the department. The other aspect of academic staff performance was research output as measured by research publications, papers presented, conferences attended and students supervised to completion.

\section{Location of The Study}

This research was done in the four Ugandan public universities. They were: Kyambogo University located in Central Uganda, Mbarara University of Science and Technology located in Western Uganda, Gulu University in Northern and Busitema University in the
Eastern region of the country. These public universities were selected based on the assumption that they have implemented HRMPs since 2011 and have good experiences and records. They also represented each region of the country. This helped in giving a more representative view from the public universities in Uganda.

\section{Target Population and Sample Size}

The study targeted directors of human resources and Vice Chancellors because they formulate and implement human resource management practices in public universities. They had reliable information on the status of human resource management practices in public universities in Uganda. The Vice Chancellors also perform a key duty to ensure that academic staff are provided with the required conditions to enhance their performance as shown in Table 3.

Table 3: Target Population and Selected Universities

\begin{tabular}{lllll}
\hline Public University & Lecturers & Director HR & Vice Chancellors & Total \\
\hline Mbarara & 256 & 1 & 1 & 258 \\
Gulu & 279 & 1 & 1 & 281 \\
Kyambogo & 415 & 1 & 1 & 417 \\
Busitema & 177 & 1 & 1 & 179 \\
Grand Total & $\mathbf{1 1 2 7}$ & $\mathbf{4}$ & $\mathbf{4}$ & $\mathbf{1 1 3 5}$ \\
\hline
\end{tabular}

Source: Ministry of Public Service, 2018 (Uganda)

To attain the right and good sample size, the researchers used a two-phase procedure for obtaining samples. The first phase involved, public universities which started before 2011 were identified since they were more likely to have well documented human resource management practices and then clustered them according to the regions. Then, universities which fall within this selection criterion were purposively selected. In the Central region, there are two public universities namely: Makerere and Kyambogo Universities; but Kyambogo was selected because Makerere had been identified to be used in the pre-test phase. Since there is one public university in each of the remaining regions that were established before 2011, each was included in the study. Mbarara University was selected from Western Uganda, Gulu University from Northern and Busitema University from the Eastern region. 
The academic staff were then finally chosen by use of simple random sampling. This ensured that the academic staff were given equal chances of participation in the study. The directors of human resources and Vice Chancellors were purposively selected.

The sample details are summarised in Table 4.

Table 4: Sample size

\begin{tabular}{llll}
\hline Public University & Regional Location & Category of respondents & Sample \\
\hline Mbarara & Western & Academic staff & 66 \\
& & Vice Chancellor & 01 \\
Gulu & \multirow{3}{*}{ Northern } & Director HR & 01 \\
& & Academic staff & 72 \\
& & Vice Chancellor & 01 \\
Kyambogo & Central & Director HR & 01 \\
& & Academic staff & 107 \\
& & Vice Chancellor & 01 \\
Busitema & \multirow{2}{*}{ Eastern } & Director HR & 01 \\
& & Academic staff & 46 \\
& & Vice Chancellor & 01 \\
Total & & Director HR & 01 \\
\hline
\end{tabular}

\section{Data Collection and Analysis}

The study used a semi-structured questionnaire for academic staff because the targeted respondents were literate. The questionnaire was used to ensure greater assurance of anonymity, encourage on the spot collection of data, produce quick results and a wide geographical area could be covered within a short time. Questionnaires also gave time to respondents to reflect on answers to avoid hasty responses to increase on the level of correctness in the collection of data.

\section{RESULTS AND DISCUSSION \\ Influence of Financial Reward on Teaching Output}

The first objective of the study examined the relationship between financial reward and academic staff teaching output in selected public universities in Uganda. It had been hypothesized that financial reward had no statistically significant correlation with academic staff teaching output. The findings revealed a weak positive correlation $(r(2)=$ $0.282, p<0.01)$ between financial reward and academic staff teaching output in public universities. The formulated null hypothesis was rejected and restated as there is a statistically weak significant relationship between financial reward and academic staff teaching output. This aspect had some influence only to a smaller extent. Therefore, financial rewards such as salary increments and benefits even when used may not necessarily enhance the quality of teaching output of academic staff. 
Exploratory factor analysis was employed to explore the components of financial reward that strongly contributed to the relationship with teaching output. Components with eigenvalues greater than 1 were considered. An oblique solution was chosen, using a Varimax rotation, to have components that are correlated with one another. The Table 5 shows that 4 components were extracted from all the aspects that measured financial reward.

\section{Table 5: Rotated Factor Matrix for Financial reward}

\begin{tabular}{|c|c|c|c|c|}
\hline \multirow[t]{2}{*}{ Aspects } & \multicolumn{4}{|c|}{ Component } \\
\hline & $\begin{array}{l}\text { Funding } \\
\text { research }\end{array}$ & \multicolumn{2}{|c|}{$\begin{array}{l}\text { Rewarding Prompt } \\
\text { performancepayment }\end{array}$} & $\begin{array}{l}\text { Rewarding } \\
\text { experience }\end{array}$ \\
\hline University does prompt salary payment to Academic Staff & & & .717 & \\
\hline $\begin{array}{l}\text { Consolidated salary encourages objective assessment of } \\
\text { students }\end{array}$ & & & .821 & \\
\hline $\begin{array}{l}\text { Annual salary increments help improve academic staff job } \\
\text { performance }\end{array}$ & & .533 & & \\
\hline University salary matches level of teaching output & & .684 & & \\
\hline University academic staff salary scale is based on seniority & & & & .526 \\
\hline Extra load allowances are promptly paid & & & & .666 \\
\hline $\begin{array}{l}\text { University academic staff are financially supported to } \\
\text { publish }\end{array}$ & .768 & & & \\
\hline $\begin{array}{l}\text { University academic staff is paid for students' research } \\
\text { supervision }\end{array}$ & .712 & & & \\
\hline $\begin{array}{l}\text { This university pays for publication of academic staff } \\
\text { research articles }\end{array}$ & .708 & & & \\
\hline $\begin{array}{l}\text { This university pays honorarium to academic staff who } \\
\text { won competitive research grants }\end{array}$ & .805 & & & \\
\hline Eigen values & 2.99 & 1.80 & 1.79 & $\mathbf{1 . 3 2}$ \\
\hline Percentage total variance & 24.97 & 15.01 & 14.94 & 10.98 \\
\hline Cumulative percentage & 24.97 & 39.98 & 54.92 & 65.9 \\
\hline
\end{tabular}

An inspection of the components indicated that component 1 is effective funding of research activities of academic staff, and accounts for $24.97 \%$ improvement, component two is rewarding good performance and accounts for $15.0 \%$ improvement. Component 3 is prompt payment and accounts for $14.9 \%$ improvement, and component 4 is rewarding experience and accounts for $10.9 \%$ improvement in research output. All the four components account for $65.9 \%$ of the variation in financial reward. Simple linear regression was done to ascertain the contribution of financial reward on research output. Scores on financial reward (Mean=40.56, $\mathrm{SD}=7.89$ ) were regressed with scores on teaching output $($ Mean $=35.14, \mathrm{SD}=$ 6.01) as shown in Table 6. 
East African Journal of Interdisciplinary Studies, Volume 2, Issue 1, 2020

Article DOI: https://doi.org/10.37284/eajis.2.1.256

Table 6: Simple Regression results of Financial reward Versus Teaching output

\begin{tabular}{llllllc}
\hline $\mathbf{R}$ & $\mathbf{R}^{\mathbf{2}}$ & Ad R $^{\mathbf{2}}$ & $\mathbf{B}$ & Beta & F Stat & Sig. \\
\hline 0.282 & .080 & .076 & 26.441 & .282 & 23.410 & $.000^{*}$ \\
\hline
\end{tabular}

*Values significant at 0.05 level (2-tailed)

Findings in Table 6 showed how financial reward contributed to teaching output as $\mathrm{R}^{2}=$ 0.08. Therefore, financial reward improved teaching output by about $8 \%$ (multiplied .080 by $100 \%)$. In other words, teaching output is dependent on the financial reward by $8 \%$. The beta and F-statistics $(23.410, \mathrm{p}<0.05)$ were positive implying that financial reward positively predicted teaching output. The Vice chancellors clarified on the role of financial reward in the teaching output of academic staff. The Vice Chancellors said that generally an academic staff in Uganda feels that:

"Lecturers are among the poorly rewarded or paid both in financial and non-financial terms. Some of the lecturers seem to be overwhelmed with family and personal needs. The government has tried to improve on lecturers' reward by enhancing their salaries. Some of the universities have invented salary top-up provisions and incentives to help improve on the packages of lecturers in public universities. This effort however, is yet to bear fruits because the promised threshold has not yet been reached where a Professor is expected to earn 15 Million Uganda Shillings.”

The Directors of human resources noted,

"...This is the reason which accounts for generally high turnover rate among the teaching staff in Higher Education Institutions in Uganda. Some of the lecturers are busy looking for money instead of settling down and develop their career path. Some of the academic staff are now full-time part-timers in other private universities which are in need of lecturers. This practice undermines teaching and outputs in research by the teaching staff in government aided universities."

Results showed the motivation academic staff got from good remuneration might increase the likelihood that they would expend effort in extra- teaching activities such as engaging in the effective preparation of course outlines, presence at campus, timely marking and release of results, forging linkages including collaborations that encourage community participation in activities of the university and making regional networks. This is in agreement with Hashim et al. (2017) who noted that financial rewards enhance the performance of employees in organisations. Kathombe, Kipchumba and Kirui (2018) further recommended that monetary benefits have great effects on staff performance. Incentives play a big role in increasing on the levels of performance. Sahoo and Mishara (2012) however, observed that financial rewards including salary increments and promotional pay are key sources of competitive advantage in any work environment. The results obtained indicate that public universities in Uganda need to scale up the level of financial rewards.

The next objective i.e., to examine the relationship between financial reward and 
academic staff research output in selected public universities in Uganda. The researcher tested the hypothesis that financial reward has no statistically significant correlation with research output of academic staff. The findings revealed a weak, but positive relationship $[r(2)$ $=0.211, p<0.01]$ between financial reward practices and academic staff research output. The formulated null hypothesis was rejected and restated as there is a statistically weak correlation between financial reward and Table 7: Simple Regression Results of Financial Reward Versus Research Output

\begin{tabular}{lllllll}
\hline $\mathbf{R}$ & $\mathbf{R}^{\mathbf{2}}$ & Ad R $^{2}$ & $\mathbf{B}$ & Beta & F Stat & Sig. \\
\hline 0.211 & .045 & .041 & 21.069 & .211 & 12.679 & $.000^{*}$ \\
\hline
\end{tabular}

*Values significant at 0.05 level (2-tailed)

Results in Table 7 showed that there was a positive contribution from financial reward to research output accounting for $\mathrm{R}^{2}=0.045$. This implied that financial reward made just a $4.5 \%$ (multiplied 0.045 by $100 \%$ ) increase in research output. The beta and F-statistics $(\mathrm{F}=12.679, \mathrm{p}<0.05)$ were positive, but rather small implying that financial reward predicted research output only to a very small extent.

The Vice Chancellors clarified on the role of financial reward in the research output of academic staff. One of the Vice Chancellors said that,

"In the last decade, academic staffs in Ugandan universities have had high tensions with the administration and government due to poor remuneration. This has affected research output because lecturers spend a lot of time and energy protesting poor pay. This has affected the level of concentration of academic staff in conducting research." academic staff research output. This implied that increasing financial rewards may not necessarily increase research output of academic staff. Simple linear regression was done to ascertain the influence of financial reward on research output. Scores on financial reward (Mean=40.56, $\mathrm{SD}=7.89)$ were regressed with scores on research output (Mean=25.97, $\mathrm{SD}=4.52$ ) as presented in Table 7. 
administrators tend to ignore their needs and instead give priorities to their travels and welfare."

The findings proved that financial rewards might be useful in motivating academic staff to get involved in research work at the university. In agreement with Akinfolarian and Ehinola (2014), in their study, they noted that when universities provide appreciations for genuine efforts and give awards to lecturers, their performance would be enhanced. Horodnic and Zait (2015), show that inadequate financial rewards may result in dissatisfaction and frustration among academic staff. This culminates into resignation with the view of taking up job positions in other institutions with generally better working conditions. Sometimes this happens even after acquiring higher degrees and qualifications at the expense of the university. It had also caused poor outputs, especially in research and innovations. Frolich and Klitkou (2014) also said that failure to adequately remunerate academic staff in terms of catering for their welfare, better education for their children, health insurances and better retirement packages. Many academic staff become worried about what lies ahead when they retire from the university service. This state of affairs ends up draining lecturers' energy to perform their duties effectively thus, resulting in poor teaching and research outputs. Quan, Chen and Shu (2016) concur that academic staff with little pay usually make decisions about quitting academia in good enough time and taking up positions that were better paying to ensure a more comfortable retirement. They also revealed that universities need to formulate relevant policy on the cash-per-publication reward policy. Terms and conditions of service should cater for lecturers' time, energy, innovativeness and inflation in the economy so that adequate rewards can be provided for academic staff in public universities. A system of differential rewards could be more appropriate.

\section{CONCLUSION}

The objective to examine the relationship between financial reward and academic staff teaching output in selected public universities in Uganda established a weak positive relationship $(\mathrm{r}(2)=0.282, \mathrm{p}<0.01)$ between financial reward and academic staff teaching output in public universities. The null hypothesis was rejected and restated as there is statistically weak positive correlation between financial reward and academic staff teaching output in public universities. Financial rewards only made an $8 \%$ contribution to teaching output. This small contribution was due to the fact that the academic staff felt poorly rewarded both in financial and non-financial aspects. This was reported by one of the directors of human resources and this made the academic staff not to see how remuneration was used to enhance their teaching and research outputs.

The next objective examined the relationship between financial reward and academic staff research output in selected public universities in Uganda. The results confirmed a weak positive relationship $(\mathrm{r}(2)=0.211, \mathrm{p}<0.01)$ had existed between financial reward practices and academic staff research output. The stated null hypothesis was rejected and restated as statistically there was a weak positive relationship between financial reward and academic staff research output. Financial reward had only made $4.5 \%$ contribution to academic staff research output. This was likely 
due to the fact that academic staff has had low motivation for research due to inadequate remuneration and incentives for research activities. Universities placed minimal emphasis on financially supporting academic staff to publish. Universities further paid little attention to financially motivate lecturers to successfully complete student's research supervision at undergraduate and graduate levels. Universities did not have adequate funds to pay for publication and honorarium paid to academic staff for research articles. The issue of honorarium to be paid to academic staff who had won the competitive research grants was also lacking and problematic.

\section{RECOMMENDATIONS}

The recommendations were based on the study results as guided by study findings and conclusions. Public universities in Uganda should provide appropriate financial rewards to academic staff based on prevailing economic conditions in the country. University management should identify key teaching activities that can be financially rewarded in order to increase the teaching outputs. Key research activities should be financially rewarded in a timely manner to promote research output among the academic staff.

\section{REFERENCES}

Agwu, M. (2013). Impact of fair reward system on employees' job performance in Nigerian Agip Oil Company Limited Port-Harcourt. British Journal of Education, Society \& Behavioural Science, 3, 47-64.

Akhter, M., Siddique, Nur, E. A., \& Alam, A. (2013). Human Resource Management Practices and its impact on Employee
Performance: A Study of the Cement Industry in Bangladesh. Global Disclosure of Economics and Business, 2(2), 125 - 132.

Akinfolarian, A. V., \& Ehinola, G. B. (2014). Motivation and Effective Performance of Academic Staff in Higher Education. A Case study of Adekunle Ajasin University, Ondo State, Nigeria. International Journal of Innovation and Research in Educational Sciences, 1, 157-163.

Akter, G., \& Husain, M. (2016). Effect of compensation on job performance: An empirical study in Bangladesh. International Journal of Engineering Technology, Management and Applied Sciences, 4(8), 103-116.

Al-Nsour, M. (2012). Relationship Between Incentives and Organisational Performance for employees in the Jordanian Universities. International Journal of Business and Management, 7(1), 78-89.

Aslam, A., Ghaffar, A., Talha, T., \& Mushtaq, H. (2015). Impact of compensation and reward system on the performance of an organisation. An empirical study on banking sector of Pakistan. European Journal of Business and Social Sciences, 4 (8), 319325.

Balakrishnan, S. (2013). Methods to increase research output: Some tips looking at the MENA region. International Journal of Emerging Markets, 3, 215-239.

Barifaijo, M. K., \& Nkata, L. J. (2009). Human Resource Management Related Factors Affecting Performance among Part-time Academic Staff in Ugandan Public 
Universities. Makerere Journal of Higher Education, 7(1).

Basheka, B. (2014). A paper presented on "The state of higher education and training in Uganda- 2013/14”. Kampala: Uganda National Council for Higher Education.

Blau, P. M. (1964). Justice in Social Exchange. Sociological Inquiry, 34, 193-206.

Chen, Y., Nixon, M. R., Gupta, A., \& Hoshower, L. (2010). Research productivity of accounting faculty: an exploratory study. American Journal of Business Education (AJBE), 3(2), 101-115.

Frolich, N., \& Klitkou, A. (2014). Strategic Management of Higher Education Institutions. Performance funding and research output. Research Gate Online.

Hashim, M., Rafi, S., Kazmi, A., Ullah, M., \& Kee, H. (2017). Impact of Human Resource Management on perceived performance. A study of teaching faculty in Private Universities of Peshawar, Pakistan. City University Research Journal, Special issue AIC Malaysia, 120-129.

HESA. (2014). Remuneration of academic staff at South African Universities. A summary report. HESA Statistical Study of Academic Staff Remuneration. Pretoria South Africa: HESA.

Homans, G. C. (1958). Social Behavior as Exchange. American Journal of Sociology, 63: 597-606.

Horodnic, A., \& Zait, A. (2015). Motivation and research productivity in a university system undergoing transition. Research Evaluation 24, 282-292.

Inspector General of Government. (2015). Report on investigations into mismanagement and corruption at Kyambogo University. Entebbe: Government Printery.

Kabasa, D. (2016). Education review road map for the reassessment of the 1992 Government White paper on Education. The Republic of Uganda: Kabasa Education Review Roadmap Team (KERR).

Kasozi, K. (2003). University education in Uganda. Challenges and opportunities for reform. Kampala: Fountain Publishers.

Kasozi, K. (2009). The Plight and Failures of the academic staff in public Universities. Kampala: University Press.

Kathombe, M. W., Kipchumba, S., \& Kirui, K. (2018). Reward management strategies and employee performance in selected Universities in Nakuru County, Kenya. Journal of Human Resource Management, 6(3), 95-102.

Krejcie, R., \& Morgan, D. (1970). Determination of sample size. Educational and Psychological Measurement, 3(30), 607-610.

Lew, T. (2009). Perceived organizational support: Linking human resource management practices with affective organizational commitment and turnover intention. Journal of International Management Studies, 4(2), 104-115. 
Mandle, C. L., Whittemore, R., \& Susan, C. K. (2001). Validity in Qualitative Research.

Mcgregor, G. P. (2007). Report of the Visitation Committee on Public Universities. Kampala: Government of Uganda.

Mugizi, W., Bukkabulindi, K., \& Bisaso, R. (2015). Framework for the study of employee commitment. Makerere University Journal of Higher Education, 7 (2), 15-47.

Musenze, S., Mayendesifuna, J., Buteeme, L., \& Lubega, M. (2013). Reward and organisational performance. An empirical study of private universities in Uganda. International Journal of Innovative Research \& Development, 2, (8), 236-447.

Mutahi, N., \& Busienei, R. (2015). Effect of Human Resource Management Practices on Performance of Public Universities in Kenya. International Journal of Economics, Commerce and Management, United Kingdom, 111 (10), 696-736.

NCHE. (2014). National Council for Higher Education. Quality Assurance Framework and Licensing Process.

NCHE. (2016/2017). National Council for Higher Education Report on accredited Higher Education Programmes in Uganda. Kampala: National Council for Higher Education.

Omuya, M. (2018). The Influence of Compensation and Rewards on employee performance in public universities in Kenya. International Journal of Economics,
Commerce and Management, l VI, (3), 700736.

Pratheepkanth, P. (2011). Reward system and its impact on employee motivation in Commercial Bank of Sri Lanka Plc in Jaffna District. Global Journal of Management and Business Research, 11(4), 85-92.

Quan, W., Chen, B., \& Shu, F. (2016). Publish or Impoverish. An investigation of the monetary reward system of science in China (1996-2016).

Rasheed, M. I., Aslam, H. D., \& Sarwar, S. (2010). Motivational issues for teachers in higher education: A critical case of IUB. Journal of Management Research, 2 (2), 1.

Sahoo, C. K., \& Mishra, S. (2012). Performance management benefits organisations and their employees. Human Resource Management Digest, 20(6), 3-5.

Tufail, S. \& Sajid, M. (2015). An empirical study of relationship between compensation, working environment and motivation of employees in Banking sector in Pakistan. Journal of Marketing and Consumer Research, 6(5), 45-56.

Uboga, R. (2019). Challenges Affecting Educational Research in Delta State Nigeria. Makerere Journal of Higher Educational, 10(2), 191 - 199.

Uganda Vision. (2016). Uganda Vision (2040). Entebbe Uganda: Entebbe Government Printery. 